\title{
Distribution of the family Littorinidae (Mollusca: Gastropoda) in Thailand
}

\author{
Kitithorn Sanpanich ${ }^{1,2}$, Fred E. Wells ${ }^{3}$ and Yaowaluk Chitramvong ${ }^{2 *}$ \\ 'The Institute of Marine Science, Burapha University, Chonburi 20131, Thailand \\ 'Biology Department, Faculty of Science, Mahidol University, Rama 6 Road, Bangkok 10400, Thailand \\ ${ }^{3}$ Western Australian Museum, Perth, Western Australia 6000, Australia \\ * Corresponding author
}

\begin{abstract}
The distribution of the family Littorinidae in mangroves and on rocky shores in Thailand was studied. Fourteen species of Littoraria, Echinolittorina and Peasiella were recorded from 50 survey sites, bringing the total known for the country to 16 species. Two species were recorded for the first time in Thailand. Littoraria conica was found in only two places in southern Thailand, both on the Andaman Sea. Echinolittorina feejeensis occurred on scattered granite rocks on sandy beaches in the splash zone of offshore islands where the water is clear both in the Gulf of Thailand and the Andaman Sea. It is dominant at Ko Kumpun, Trat Province. Habitats occupied by the three genera are distinct. Echinolittorina and Peasiella occur primarily on intertidal rocks though occasional individuals are found in the seaward fringe of mangroves; Littoraria undulata occupies a similar rock habitat. The other species of Littoraria occur on many species of mangroves, with some occasionally being found on rocks. Four species (L. bengalensis, $L$. conica, $L$. scabra, and L. undulata) occurred only on the Andaman Sea side of Thailand. Littoraria bengalensis is restricted to the Indian Ocean but the other three species occur in the Pacific Ocean east of Thailand. Their absence in the Gulf of Thailand appears to be real.
\end{abstract}

\section{INTRODUCTION}

The family Littorinidae is a moderately diverse group of intertidal gastropods. Reid (1989a) reported there were 173 species, and more species have since been described. The family is most diverse in the Indo-West Pacific Ocean. Rosewater $(1970,1972)$ examined the distribution of the family in the entire Indo-Pacific using records from the major museum collections. He considered there to be one subspecies of the mangrove littorine, Littorina scabra, a view reiterated in a subsequent paper (Rosewater, 1980). Reid (1986a) was able to examine the species in a wide range of field localities and determined there was a suite of 20 species inhabiting different parts of the mangroves and rocky shores. He transferred the group to the genus Littoraria. He later (Reid, 1999) extended the study of Littoraria into the eastern Pacific. Reid subsequently expanded his research into several other genera of tropical Indo-Pacific littorinids, including Mainwaringia (Reid, 1986b), Peasiella (Reid, 1989b; Reid and Mak, 1998), Nodilittorina (Reid, 2001a), and a paper on the littorinids of Hong Kong (Reid, 1992). Williams et al. (2003) transferred the tropical Indo-Pacific Nodilittorina species to Echinolittorina. Reid also recorded three species of Indo-West Pacific littorines in the eastern Pacific (Reid and Kaiser, 2001). Despite their intertidal nature and the tendency for a widespread distribution, new species of Indo-Pacific littorines continue to be found, including species of Littoraria (Reid, 2001b; Stuckey and Reid, 2002) and Tectarius (Reid and Geller, 1997). Many of the papers cited above have recorded species of littorinids in Thailand as part of broad distributional studies, but the Littorinidae of Thailand have not been examined in detail. Altogether, 14 species of littorinids have been recorded, including nine Littoraria, three Echinolittorina and two Peasiella. McQuaid (1996a; 1996b) presented a general review of the biology of littorinids.

Molluscs are an important component of the fauna of mangrove communities in the tropical and subtropical Indo-West Pacific, including Thailand. They are diverse (Macnae, 1967, 1968; Saenger et al., 1977), and many species have a high density and/ or biomass (Brown, 1971; Wells, 1983, 1984, 1986). Species living in mangroves can be divided into those that are found on adjacent rocky, sandy and muddy shores, and which simply use mangroves as an incidental habitat, and species that are restricted to mangroves. Cantera et al. (1983) concluded that only $20 \%$ of the gastropods in mangroves are species restricted to the tree zones. These characteristic mangrove species are often numerically dominant and ecologically important. Many have developed mechanisms such as resorbing calcium carbonate from internal shell 
structures which allow them to survive in this difficult habitat (Vermeij, 1974, 1978). While there are numerous species of molluscs living in mangroves, there is very little information on their lifespan or population dynamics. Littoraria is particularly interesting as a mangrove mollusc genus, as most of the species occur only in mangroves, where they are the dominant molluses in the trees, while most other mangrove gastropods live on the ground.

Most of the records of littorinids in Thailand are based on museum material collected over many years, but there have been several studies which examined distribution and/or biology of the group. Frith et al. (1976) studied zonation of macrofauna on a mangrove shore at Phuket Island. Details of the littorinids collected in this study were reported in a short paper by Nielsen (1976). As part of a broader study of habitat and zonation patterns of Littoraria in the Indo-West Pacific, Reid (1985) included sites at Phuket Island and Kanchanadit. Cook and Garbett (1989) detailed patterns of variation in mangrove littorinids at Phuket Island.

The records of littorinids in Thailand are generally patchy, with only a few localities recorded for a country with extensive coastlines on the Pacific Ocean (Gulf of Thailand) and in the eastern Indian Ocean. The present paper is the first detailed examination of littorinids in Thailand as a basis for understanding where the species occur in Thailand to facilitate future work on their biology.

\section{MATERIALS AND METHODS}

Snails used in this study were collected from November 2001 to August 2003 from all coastal parts of Thailand, including the eastern provinces (Chonburi, Rayong, Chanthaburi and Trat), the middle provinces (Samut Prakan and Samut Songkram), the east coast of the southern provinces (Phetchaburi, Prachuab Khiri Khun, Chumphon, Surat Thani, Nakhon Si Thammarat, Pattani, and Narathiwat) and the west coast of the southern provinces (Ranong, Phang Nga, Phuket, Krabi, Trang, and Satun).

Adult specimens of similar sizes were collected by hand in two habitats. Specimens were collected from roots, trunks and leaves in mangrove areas and some animals were collected from nearby mud. Other species were collected in the splash zone of rocky shores along the islands. One to three habitats were examined at each locality. After collection, all specimens were narcotised in a $7.5 \%$ (weight/ volume) solution of magnesium chloride (Reid, $2000,2001 \mathrm{~b})$ then fixed in $10 \%$ formalin and retained for later dissection and identification. Representative material of all species is retained in the mollusc collections of the Burapha Institute of Marine Science, Burapha University.
Rosewater (1970,1972) and Reid (1986a and other papers) described the shells and anatomy of these species. As they can usually be identified from shells alone, the details are not repeated here. As Reid (1986a) is not widely available in Thailand, shell photographs of all species collected are presented in Figures 1 and 2. Littoraria strigata and L. articulata are unusual in that they cannot be differentiated by their shells. Males are readily determined using the structure of the penis (Figure 2). As the differentiation of females is subtle, all records in this paper are based on males. The dendrogram was calculated using the Statistical Package in the Social Sciences (SPSS), Version 11.0.

\section{RESULTS}

Fourteen species: 10 Littoraria, 3 Echinolittorina and 1 Peasiella were recorded from 50 survey sites (Figure 3, Appendix 1, Table 1). The number of stations at which each species was found ranged considerably, from 32 for L. strigata to 2 for L. conica. Aside from $L$. strigata, the other widespread species were E. trochoides (26 stations), L. articulata (19), E. vidua (17), L. pallescens (17), L. melanostoma (16), and L. carinifera (14). The 10 species of Littoraria occurred at a mean of $11.5 \pm 9.8$ (SE) stations, the three Echinolittorina at a mean of $16.7 \pm 5.5$, and the single Peasiella at seven stations. It was interesting that the two species which are indistinguishable on the basis of shell morphology, L. articulata and L. strigata cooccurred at all 19 of the stations at which $L$. articulata was found. In addition, L. strigata was found at 13 stations where L. articulata did not occur.

Habitats occupied by the three genera are distinct. Nine of the 10 species of Littoraria occur primarily on mangroves (Table 1). They tend to occur on a wide range of mangrove and other plant species in the community. In all Littoraria were recorded from a total of 17 species of plants. The mean number of plant species inhabited by the mangrove Littoraria was $9.2 \pm 1.2$. The common species occurred on a wide range of plants: L. carinifera was found on 14 species, $L$. melanostoma and $L$. pallescens on 13 , and $L$. articulata on 11. Many of these species also were found on house or pier poles, which were often of wood. Several were also found on rocky shores, but this constituted only a small portion of the population. It was noteworthy that four species ( $L$. articulata, $L$. carinifera melanostoma and $L$. strigata) were found on mud or sand among the mangroves. This was a natural occurrence, and not simply that the animals were inadvertently brushed off the trees by the investigator. Littoraria collected in this study were most abundant near the seaward margins of the mangroves; density declined sharply with distance from the edge of the mangroves. Aside from L. pallescens, most individuals were found $<50 \mathrm{~cm}$ 


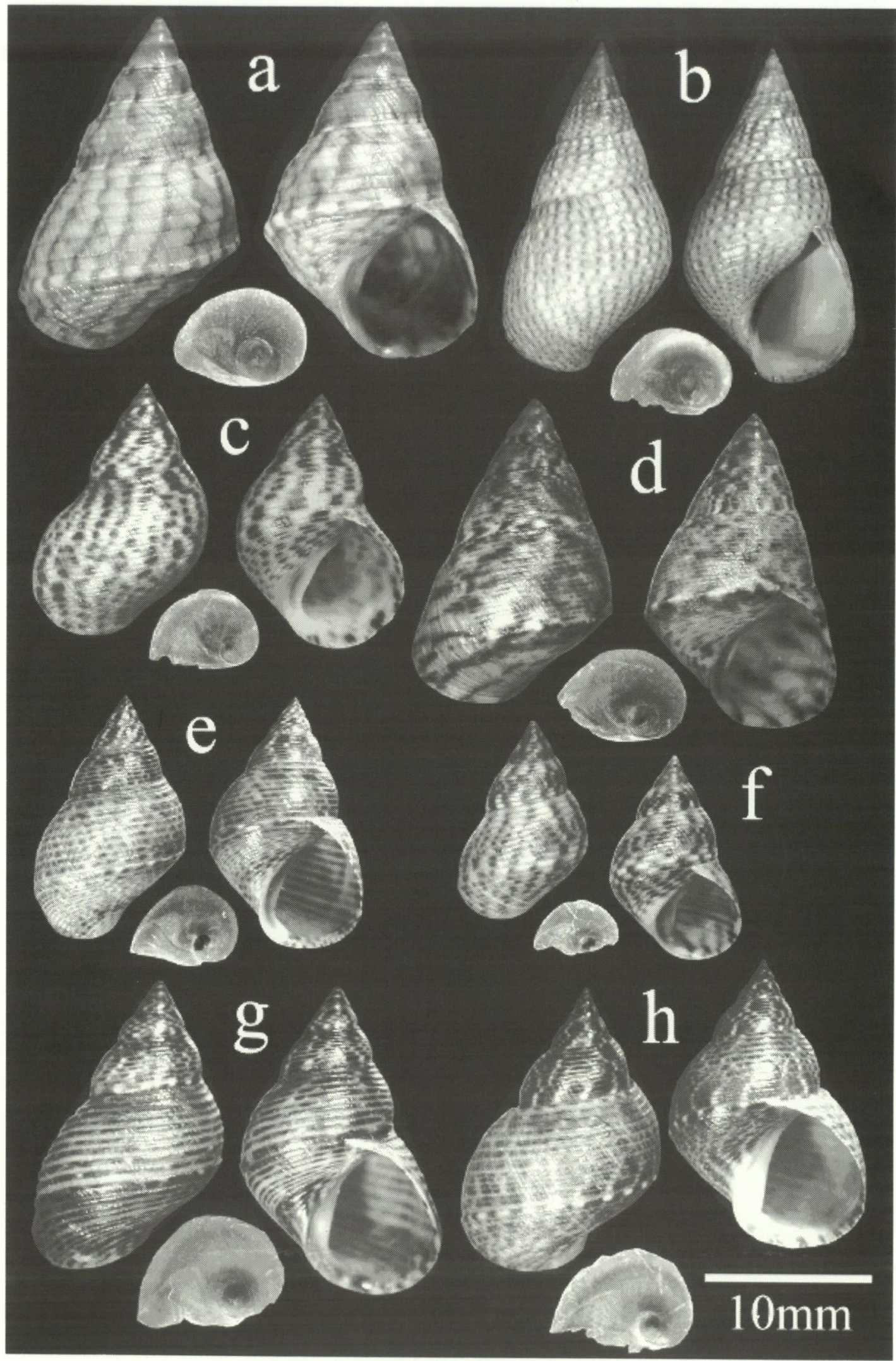

Figure 1 Littorinids recorded from Thailand. a. L. carinifera, Ban Jebilung, Amphur Moeng, Satun Province (BIMSM1175) b. L. melanostoma, E-led canal, Chumphon Islands Marine Park, Tumbon Hadsairee, Amphur Moeng, Chumphon Province (BIMS-M1176) c. L. articulata, Samed, Amphur Moeng, Chonburi Province (BIMSM1177) d. L. conica, Ban Jebilung, Amphur Moeng, Satun Province (BIMS-M1178) e. L. bengalensis, Chaomai Beach, Tumbon Ko Libong, Amphur Kuntung, Trang Province (BIMS-M1179) f. L. intermedia, Mai ngarm Bay, Ko North Surin, Phangnga Province (BIMS-M1180) g. L. pallescens, Ban Dee, Tumbon LaemPo, Amphur Yaring, Pattani Province (BIMS-M1181) h. L. scabra, Mai ngarm Bay, Ko North Surin, Phangnga Province (BIMS-M1182) 


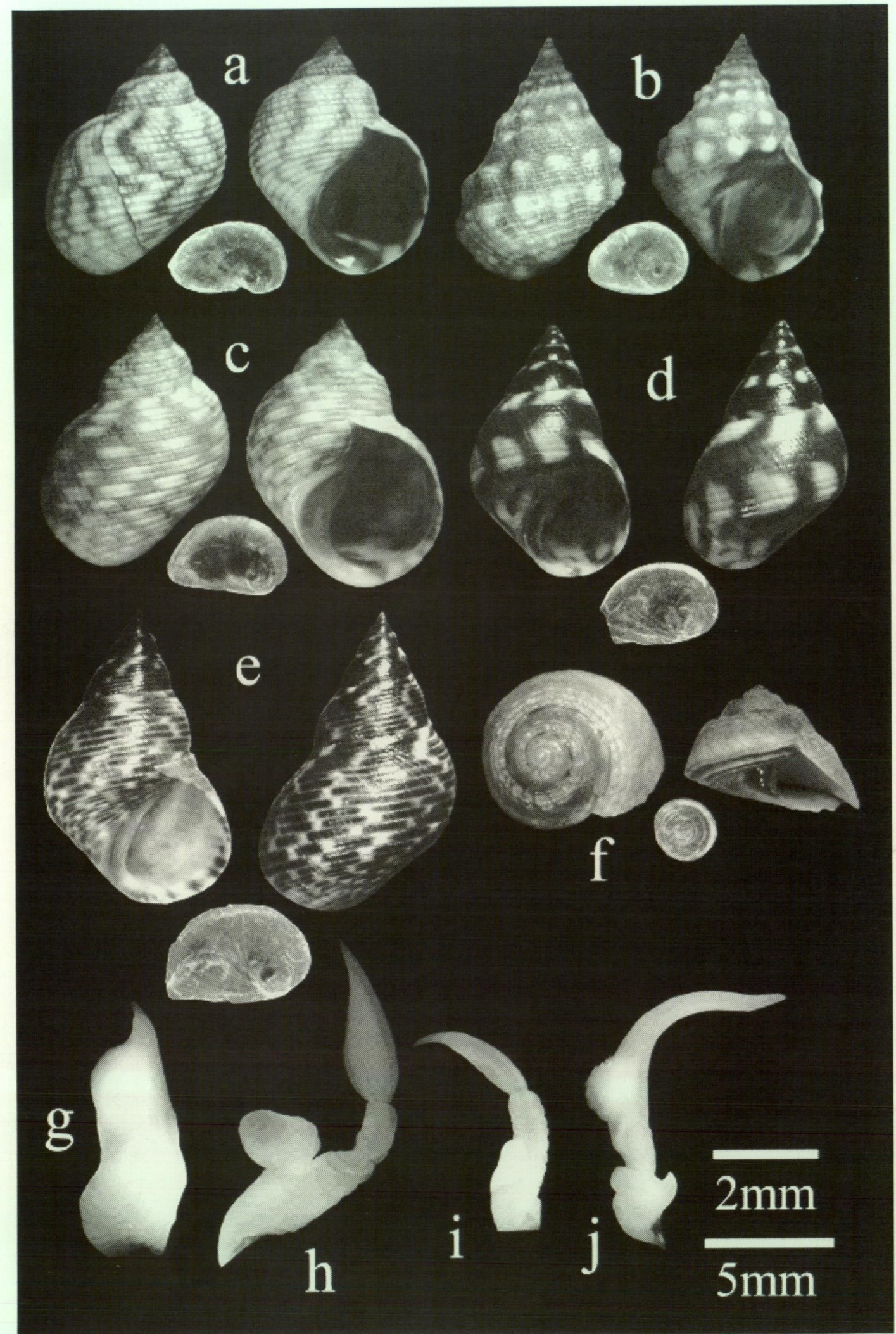

Figure 2 Littorinids recorded from Thailand. a. E. feejeensis, Ko Kumpun.(BIMS-M1185) b. E. trochoides, Ko Prao-nok, Sub-amphur Ko Chang.(BIMS-M1186) c. E. vidua, Yai Bay, Sub-amphur Ko Kut, Trat Province.(BIMS-M1187) d. L. undulata, Had Kalim, Amphur Kratu, Phuket Province.(BIMS-M1183) e. L. strigata, Ban Cha-ngoe, Tumbon Takienthong, Amphur Kanjanadit, Surat Thani Province.(BIMS-M1184) f. P. roepstorffiana, Mai ngarm Bay, Ko North Surin, Phangnga Province.(BIMS-M1188) g. Penis of L. articulata, Samed, Amphur Moeng, Chonburi Province. h. Penis of L. bengalensis, Chaomai Beach, Tumbon Ko Libong, Amphur Kuntung, Trang Province. i. Penis of L. intermedia, Mai ngarm Bay, Ko North Surin, Phangnga Province. j. Penis of $L$. strigata, Ban Cha-ngoe, Tumbon Takienthong, Amphur Kanjanadit, Surat Thani Province. Scales for a - e = $5 \mathrm{~mm} ; \mathrm{f}-\mathrm{j}=2 \mathrm{~mm}$. 
Table 1 Habitats occupied by littorinids in Thailand

$\begin{array}{cc}\text { No. } & \text { Habitats occupied } \\ \text { stations } & \end{array}$

Littoraria articulata

(Philippi, 1846)

Littoraria bengalensis

Reid, 2001

Littoraria carinifera

(Menke, 1830)

Littoraria conica

(Philippi, 1846)

Littoraria intermedia

(Philippi, 1846)

Littoraria melanostona

(Gray, 1839)

Littoraria pallescens

(Philippi,1846)

Littoraria scabra

(Linnaeus, 1758)

Littoraria strigata

(Philippi, 1846)

\section{Rocky shore species}

Littoraria undulata

(Gray, 1839)

Echinolittorina fecjeensis

(Reeve, 1857)

Echinolittorina trochoides

(Gray, 1839)

Echinolittorina vidua

(Gould, 1859)

Peasiella roepstorffiana

(Nevill, 1885)
19

Rocks and seawalls, house and pier poles, muddy sand, mangroves:

Rhizophora mucronata, Rhizophora apiculata, Avicennia alba, Avicennia marina, Sonneratia alba, Sonneratia griffithii, Sonneratia caseolaris, Lumnitzera racemosa, Ceriops decandra, Ceriops tagal. Sedge: Sesuvium portulacastrum

6 Mangroves: A. alba, A. marina, S. griffithii, R. apiculata, C. decandra, Aegialites rotundifolia. Ground cover: Finlaysonia maritima.

14 Rocks and seawalls, house and pier poles, muddy sand, mangroves: $R$. apiculata, R. mucronata, A. alba, A. marina, C. tagal, Bruguiera cylindrica, Xylocarpus granatum, S. griffithii, L. racemosa, C. decandra, A. rotundifolia. Nypa fruticans. Climber: F. maritima. Sedge: S. portulacastrum.

2 Mangroves: R. apiculata, R. mucronata, C. decandra and A. rotundifolia Climber: F. maritima

3 Rocks and seawalls, mangroves: R. apiculata, A. alba, A. marina and S. griffithii

16 Rocks and seawalls, muddy sand, mangroves: A. marina, A. alba, R. apiculata, R. mucronata, S. griffithii, S. caseolaris, S. alba, C. decandra, A. rotundifolia, $L$. racemosa, C. tagal. Sedge: S. portulacastrum. Climber: F. maritima,

17 Rocks and seawalls, house and pier poles, mangroves: $R$. apiculata, $R$. mucronata, A. alba, A. marina, S. griffithii, S. alba, L. racemosa, C. decandra, C. tagal, B. cylindrical, X. granatum and A. rotundifolia Palm: Nypa fruticans.

3 Rocks and seawalls, mangroves: R. mucronata, R. apiculata, A. alba, A. marina and S. griffithii

32 Rocks and seawalls, house and pier poles, muddy sand, mangroves: $R$. mucronata, R. apiculata, A. alba, A. marina, S. alba, S. griffithii, S. caseolaris, $L$. racemosa, C. decandra, C. tagal. Sedge: S. portulacastrum

Rocks and seawalls

Rocks and seawalls

Rocks and seawalls, mangroves: R. apiculata and A. marina

Rocks and seawalls, mangroves: A. marina

Rocks and seawalls from the sediment, and few were above $1 \mathrm{~m}$. On the lower parts of the trees they occurred widely on trunks, pneumatophores, branches, and leaves. Littoraria pallescens occurred primarily in the foliage higher up on the trees at heights of up to $5 \mathrm{~m}$. Echinolittorina and Peasiella occur on primarily on intertidal rocks though occasional individuals were found in the seaward fringe of mangroves; Littoraria undulata occupied a similar rock habitat.

A dendrogram calculated on the occurrences of all species at all 50 stations (Figure 4) demonstrates that there are two clear assemblages: seven species of Littoraria which live in close association with mangroves, and seven species which tend to occur on rocky shores, though they also occur in mangroves. The latter group includes the rocky shore L. undulata and two mangrove species, $L$. intermedia and L. scabra.

\section{DISCUSSION}

Rosewater (1970, 1972) and Reid (1986a, 1989b, 2001a, 2001b; Reid and Mak, 1998) reported 14 species of littorinids in three genera in Thailand as part of their broader surveys of Indo-Pacific Littorinidae. All except two of these species were reported in the present paper, with many additional localities presented for most species. Reid (2001) found Echinolittorina reticulata along the western coast of Thailand but it was not found in the present study. Peasiella patula was recently described from Singapore by Reid and Mak (1998), with a record of Pattaya, Thailand included in the description. A trip was made to Pattaya and the nearby islands to search for this species, but the record could not be confirmed. Two species were recorded for the first time in Thailand. Littoraria conica was found in only two places in southern Thailand, both on the 

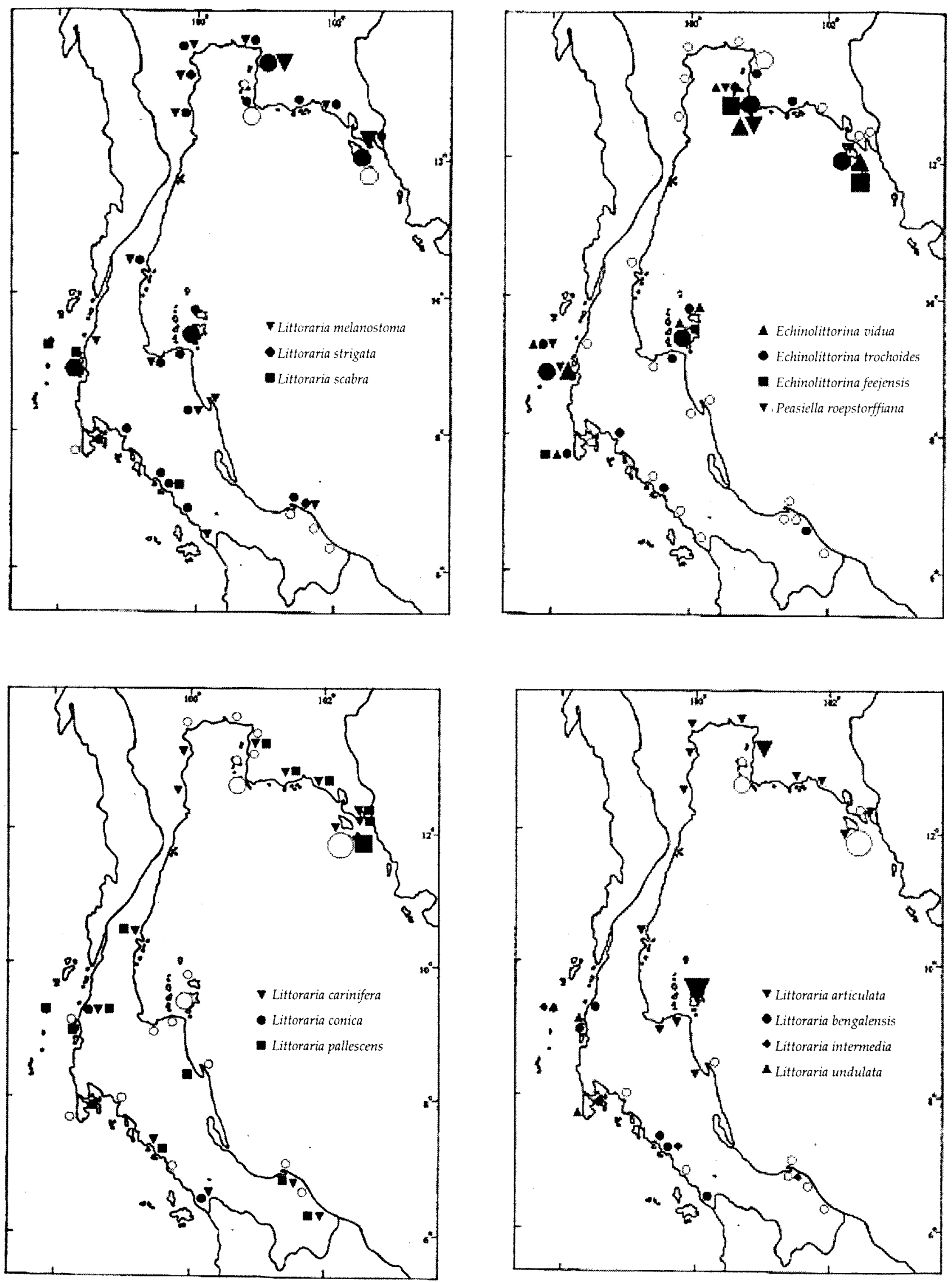

Figure 3 Distribution maps of littorinids in Thailand. Empty circles represent stations at which none of the mapped species were found. Larger symbols indicate records from more than one station that are too close to separate on the map. 


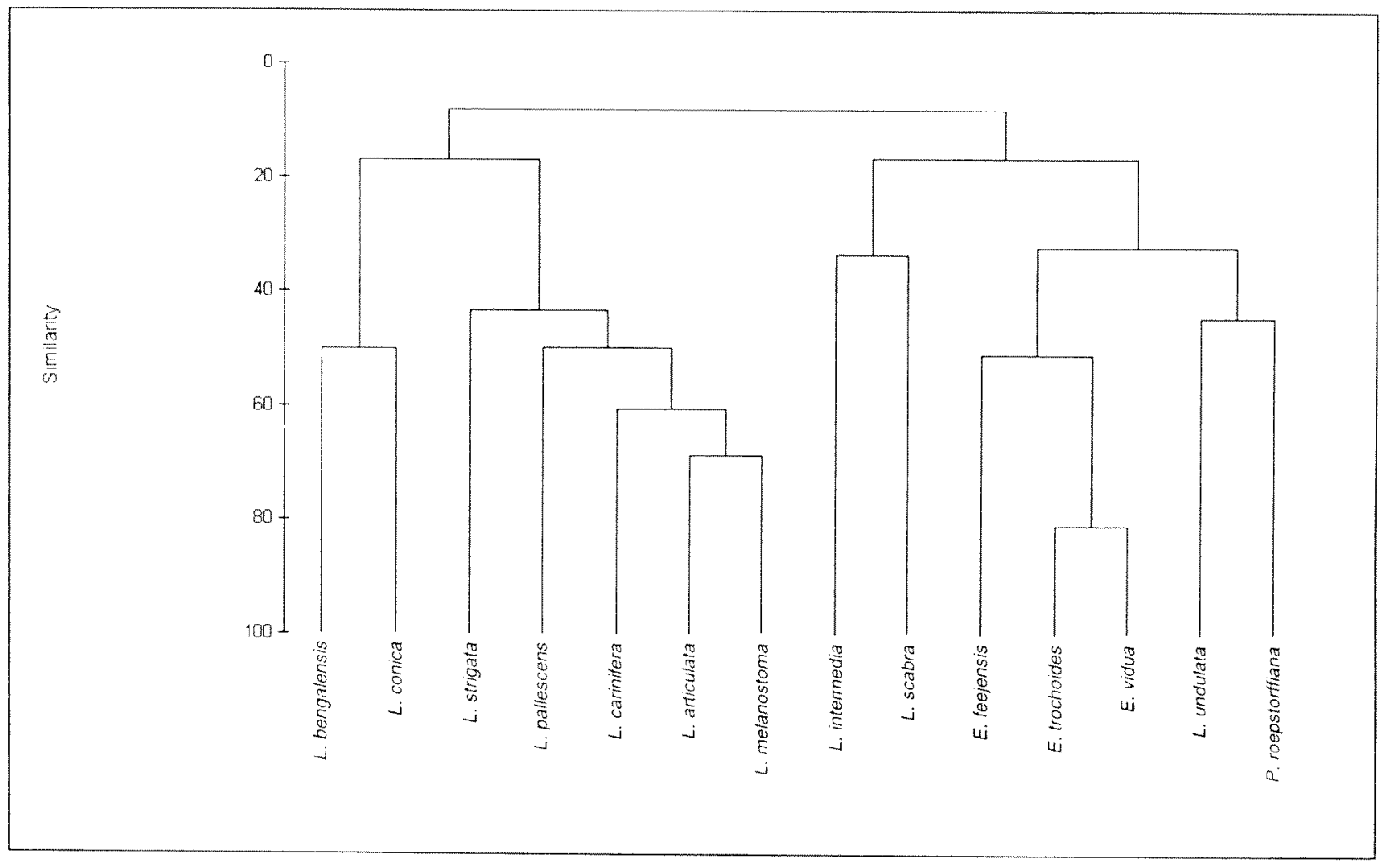

Figure 4 Dendrogram of similarity of littorinids collected at 50 stations in Thailand.

Andaman Sea. Echinolittorina feejeensis occurred on scattered granite rocks on sandy beaches in the splash zone of offshore islands where the water is clear both in the Gulf of Thailand and the Andaman Sea. It is dominant at Ko Kumpun, Trat Province. Altogether, there have now been 16 species of Littorinidae recorded in Thailand.

The two coasts of Thailand are both part of the vast Indo-West Pacific faunal region. While the Indo-West Pacific is considered to be a distinct biogeographical region, it is well known that there are some differences between the biota of the western Pacific Ocean and eastern Indian Ocean. Most mollusc species are widespread throughout the region. Wells (2002) studied distribution patterns of 1268 species of shallow water molluscs in the Indo-West Pacific, including littorinids. Diversity was higher (745 species) in the coral triangle, which included the Pacific coast of Thailand than in the eastern Indian Ocean $(542$ species), which included the Andaman Sea coast of Thailand. A small proportion $(<6 \%)$ of the molluscs were restricted to one of the two areas. Recent studies (e.g. Benzie, 1999; Williams et al., 2002) have shown that the distinction between Indian and Pacific Ocean populations also occurs at a genetic level within a single species. The reasons for the separation of the two areas are complex. At present the oceans are continuous, which allows at least some genetic exchange between the two areas.
During Pleistocene periods of lower sea level the tropical portions of the two oceans were separated, allowing allopatric speciation to occur. The most recent period of lowered seawater was approximately 18,000 years ago, when sea levels were $130 \mathrm{~m}$ lower than now (Chappel and Shackleton, 1986).

The distribution of littorinids in Thailand fits into this general pattern. Most (10) of the littorinids found in the present study occurred on both coasts of Thailand, including all of the species of Echinolittorina and Peasiella, and most of the Littoraria. Four of the Littoraria (L. bengalensis, $L$. conica, L. scabra, and L. undulata) occurred only on the Andaman Sea side of the country. The known distribution of $L$. bengalensis is restricted to the Indian Ocean between India and Thailand (Reid, 1999). Reid (1986a) records L. conica and L. scabra from sites in the Pacific Ocean east of Thailand, and Rosewater (1970) presents similar data for $L$. undulata, and the species have been found in peninsular Malaysia. However, neither author records these species in the Gulf of Thailand. Granted the relatively few sites that had been examined in the Gulf of Thailand, the absence of records in the Gulf could have been real or an artefact of the lack of samples. The present study demonstrates the absence is real.

In most respects, the habitats occupied by Littoraria in Thailand are similar to those reported 
by Reid (1985; 1986a, 2001b), though individual species in Thailand occur on mangroves from which they were previously not recorded. In fact, individual species were found on up to 14 different plant species. Reid (1985) showed that individual species are zoned on the shoreline. The present study demonstrates that the zonation is not specific to a particular type of tree, or necessarily even restricted to trees, but at the right tidal height species living in mangroves will inhabit a wide variety of trees. Some are also found on rocky or other wooden substrates, as noted by Reid (1986a). The main habitat difference that we found is a small proportion of several species, such as $L$. strigata, $L$. articulata and L. melanostoma, occurring on intertidal sand and mud among the mangroves, including the seaward pneumatophore zone. These animals were actively crawling between the pneumatophores and had not been dislodged from an overhanging part of the mangrove. Perhaps the presence of a small proportion of the populations on the mud surface is due to the moister conditions and heavier rainfall in Thailand compared with Townsville, Australia, where Reid (1986a) did most of his work. He also (Reid, 1985) worked in other areas, including two localities in Thailand, but did not find Littoraria on the mud surface in the other areas he examined.

Aside from $L$. undulata, all of the Littoraria species found in Thailand were mangrove species. Reid (1986a) reported that at least three of the Littoraria species living in mangroves are "oceanic" species which live in less turbid water than "continental" species which live in areas of greater turbidity. The "oceanic" species are L. intermedia, L. pallescens and L. scabra. The dendrogram (Figure 4) provides some support for this hypothesis. There is a clear grouping of rocky shore species comprised of the three species of Echinolittorina, one species of Peasiella roepstorffiana and $L$. undulata. Two of the three "oceanic" species (L. intermedia and L. scabra) have a loose association with the rocky shore species. The combination of rocky shore and mangrove habitats occupied by the two species allows them to live in both coastal and oceanic regions. However, the third "oceanic" species, $L$. pallescens, is clearly grouped with the Littoraria species found in mangroves, not with the rocky shore species. Examination of the distributional maps presented by Reid (1986a) indicates that the three "oceanic" species occur in the open water areas of the Pacific Ocean but also in the muddier waters of southeast Asia, including Thailand and the Malaysian peninsula. An alternative hypothesis is that diversity of Littoraria is greatest in the southeast Asian area, and decreases with increasing distance in all directions (east, west, north and south) in the Indo-Pacific. This parallels the general distributional pattern found in molluscs (e.g. Wells, 2002) and many other groups. In this context, the distributional patterns of Littoraria are consistent with the centre of biodiversity in the 'coral triangle', with lower diversity with increasing diversity from the central triangle rather than a division into "continental" and "oceanic" species.

\section{ACKNOWLEDGEMENTS}

Dr David Reid of the Natural History Museum, London, kindly confirmed our species identifications and commented on a draft of this paper. This paper was submitted in partial fulfilment of the requirements for the $\mathrm{PhD}$ program at Mahidol University by Kitithorn Sanpanich, who had a Royal Golden Jubilee Scholarship from the Government of Thailand. We are particularly grateful to Dr Pichai Sonchaeng, Director of the Burapha Institute of Marine Sciences and Dr Maleeya Kruatrachue, Head, Dept. of Biology, Mahidol University, for access to facilities in their departments.

\section{REFERENCES}

Benzie, J.A.H. 1999. Major genetic differences between Crown of Thorns starfish (Acanthaster planci) populations in the Indo-Pacific oceans. Evolution 53: 1782-1795.

Brown, D.S. 1971. Ecology of Gastropoda in a South African mangrove swamp. Proceedings of the Malacological Society of London 39: 263-279.

Cantera, J., Arnaud, P. and Thomassin, B.A. 1983. Biogeographical and ecological remarks on molluscan distribution in mangrove biotopes. 1. Gastropods. Journal of Molluscan Studies (Supplement) 12A: 10-26.

Chappell, J. and Shackleton, N.J. 1986. Oxygen isotopes and sea level. Nature 324: 137-140.

Cook, L.M. and Garbett, S.B. 1989. Patterns of variation in mangrove littorinid mollusks on Phuket Island. Phuket Marine Biological Center Special Publication 53: 1-14.

Frith, D.W., Tantanasiriwong, R. and Bhatia, O. 1976. Zonation of macrofauna on a mangrove shore, Phuket Island. Research Bulletin of the Phuket Marine Biological Center 10: 1-37.

Macnae, W. 1967. Zonation within mangroves associated with estuaries in north Queensland. Pp. 419-424. In: Lauff, G.H. (Ed.) Estuaries. American Association for the Advancement of Science Publication 83.

Mak, Y.M. and Williams, G.A. 1999. Littorinids control high intertidal biofilm abundance on tropical Hong Kong rocky shores. Journal of Experimental Marine Biology and Ecology 233: 81-94.

McQuaid, C.D. (1996a). Biology of the gastropod family Littorinidae. I. Evolutionary aspects. Oceanography and Marine Biology Annital Review 34: 263-302.

McQuaid, C.D. (1996b). Biology of the gastropod family Littorinidae. II. Role in the ecology of intertidal and shallow water marine ecosystems. Oceanography and Marine Biology Annual Review 34: 263-302. 
Reid, D.G. 1985. Habitat and zonation patterns of Littoraria species (Gastropoda: Littorinidae) in IndoPacific mangrove forests. Biological Journal of the Linnean Society 26: 39-68.

Reid, D.G. 1986a. The littorinid mollusks of mangrove forests in the Indo-Pacific region the genus Littoraria. London: British Museum (Natural History).

Reid, D.G. 1986b. Mainwaringia Nevill, 1885, a littorinid genus from Asiatic mangrove forests, and a case of protandrous hermaphroditism. Journal of Molluscan Studies 52: 225-242.

Reid, D.G. 1989a. The comparative morphology, phylogeny and evolution of the gastropod family Littorinidae. Philosophical Transactions of the Royal Society of London B 324:1-110.

Reid, D.G. 1989b. Systematic revision of the Recen species of Peasiella Nevill, 1885 (Gastropoda: Littorinidae), with notes on the fossil species. The Nautilus 103(2): 43-69.

Reid, D.G. 1992. The gastropod family Littorinidae in Hong Kong. In: Morton B, editor. The marine flora and fauna of Hong Kong and Southern China III. Proceedings of the Fourth International Marine Biological Workshop: The marine flora and fauna of Hong Kong and Southem China, Hong Kong; 1989 April 11-29; Hong Kong: Hong Kong University Press: 187-210.

Reid, D.G. 1996. Systematics and evolution of Littorina. Hampshire: The Ray Society.

Reid, D.G. 1999. The genus Littoraria Griffith \& Pidgeon, 1834 (Gastropoda: Littorinidae) in the Tropical Eastern Pacific. The Veliger 42: 21-53.

Reid, D.G. 2000. Preservation and curation of marine molluscan specimens. Phuket Marine Biological Center Special Publication 21: 583-590.

Reid, D.G. 2001a. The genus Nodilittorina von Martens, 1897 (Gastropoda: Littorinidae) in the Indo-Malayan Region. Phuket Marine Biological Center Special Publication 25: 433-449.

Reid, D.G. 2001b. New data on the taxonomy and distribution of the genus Littoraria Griffith \& Pidgeon, 1834 (Gastropoda: Littorinidae) in Indo-West Pacific mangrove forests. The Nautilus 115: 115-139.

Reid, D.G. and Geller, J.B. 1997. A new ovoviviparous species of Tectarius (Gastropoda: Littorinidae) from Niue, South Pacific, with a molecular phylogeny of the genus. Journal of Molluscan Studies 63: 207-233.

Reid, D.G. and Kaiser, K. L. 2001. Three new records of Indo-West Pacific Littorinidae (Gastropoda) in the Tropical Eastern Pacific. The Veliger 44: 381-388.

Reid, D.G. and Mak, Y. 1998. Additions and corrections to the taxonomy of the genus Peasiella Nevill, 1885 (Gastropoda: Littorinidae). The Nautilus 112: 6-33.

Rosewater, J. 1970. The family Littorinidae in the IndoPacific Part I. The subfamily Littorininae. Indo-Pacific Mollusca 2: 417-506.
Rosewater, J. 1972. The family Littorinidae in the IndoPacific Part II. The subfamilies Tectariinae and Echininae. Indo-Pacific Mollusca 2: 507-528.

Rosewater, J. 1980. Subspecies of the gastropod Littorina scabra. Nautilus 94: 158-162.

Saenger, P., Specht, M.M., Specht, R.L. and Chapman, V.J. 1977. Mangal and coastal salt-marsh communities in Australasia. Pp. 293-346. In: Chapman, V.J. (ed). Ecosystems of the world. Volume 1. Wet coastal ecosystems. Elsevier, Amsterdam.

Stuckey, M. and Reid, D.G. 2002. A new Littoraria (Gastropoda: Littorinidae) from northwestern Australia. Molluscan Research 22: 1-16.

Vermeij, G.J. 1974. Molluscs in mangrove swamps: Physiognomy, diversity and regional differences. Systematic Zoology 22: 609-624.

Vermeij, G.J. 1978. Biogeography and Adaptation. Patterns of Marine Life. Harvard University Press, Cambridge, Massachusetts.

Wells, F.E. 1983. An analysis of marine invertebrate distributions in a mangrove swamp in northwestern Australia. Bulletin of Marine Science 33: 736-744.

Wells, F.E. 1984. Comparative distribution of macromolluscs and macrocrustaceans in a Northwestern Australian mangrove system. Australian Journal of Marine and Freshwater Research 35: 591-596.

Wells, F.E. 1986. Distribution of molluscs across a pneumatophore boundary in a small bay in Northwestern Australia. Journal of Molluscan Studies 52: 83-90.

Wells, F.E. 2002. Centres of species richness and endemism of shallow water marine molluscs in the tropical Indo-West Pacific. Proceedings of the $9^{\text {th }}$ International Coral Reef Symposium, Bali, Indonesia 2327 October 2000. Kasim Moosa, M., Soemodihardjo, S., Soegiarto, A., Romimohtarto, K. Nontji, A., Soekrano and Suharsono (eds.). Ministry of Environment, Indonesian Institute of Sciences and International Society for Reef Studies, Jakarta, Indonesia. Pp. 941945.

Williams, S.T., Jara, J.A., Gomez, E. and Knowlton, N. 2002. The marine Indo-West Pacific break: contrasting the resolving power of mitochondrial and nuclear genes. Integrative and Comparative Biology 42: 941-952.

Williams, S.T., Reid, D.G., and Littlewood, D.T.J. 2003. A molecular phylogeny of the Littorininae (Gastropoda: Littornidae): unequal evolutionary rates, morphological parallelism and biogeography of the Southern Ocean. Molecular Phylogenetics and Evolution 28: 60-86.

Manuscript received 30 April 2004; accepted 3 June 2004 
Appendix 1 Descriptions of sites examined for littorinids in Thailand.

Site 1. Yai Bay, Ko Kut, Ko Kut sub-amphur, Trat (11 ${ }^{\circ} 36^{\prime} 37.5^{\prime \prime N}$; 102 ${ }^{\circ} 35^{\prime 38.5 " E) ~} 5$ Apr 2002. Rocky shore. $L$. pallescens, L. strigata, E. feejeensis, E. trochoides, E. vidua, $P$. roepstorffiana. Site 2 . South of Ko Rad, Ko Kut subamphur, Trat $\left(11^{\circ} 40^{\prime} 22^{\prime \prime N}\right.$; 102 $31^{\prime} 35.5^{\prime \prime}$ ) 19 Nov 2001 Sandy beach with rocks. L. strigata, E. feejeensis, E. trochoides, E. vidua. Site 3. Hin Kongwaichaek, Ko Chang, Trat (11 $\left.{ }^{\circ} 57^{\prime} 21.2^{\prime \prime} \mathrm{N} ; 102^{\circ} 21^{\prime} 41.6^{\prime \prime} \mathrm{E}\right) .18$ Nov 2001 Rocky shore. E. trochoides, E. vidua. Site 4. Ko Krum, Ko Chang,

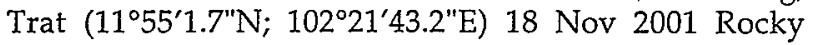
shore. L. pallescens, E. trochoides. Site 5. Ko Karm, Mak Is.,

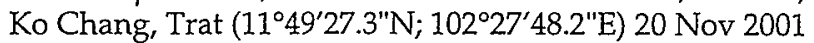
Rocky shore. E. trochoides, E. vidua. Site 6. East of Ko Ra yungnork, Mak Is., Ko Chang, Trat $\left(11^{\circ} 41^{\prime} 17.8^{\prime \prime N}\right.$; 102'27'16.6"E) 20 Nov 2001 Rocky shore. E. trochoides, E. vidua. Site 7. Ko Kumpun, Mak Is., Ko Chang, Trat (11 $\left.46^{\prime} 35.9^{\prime \prime} \mathrm{N} ; 102^{\circ} 21^{\prime} 48.6^{\prime \prime} \mathrm{E}\right) 21$ Nov 2001 Rocky shore. $E$. feejeensis, E. trochoides, E. vidua. Site 8 . Ko Prao nok, Ko Chang, Trat $\left(11^{\circ} 58^{\prime} 15.5^{\prime \prime N}\right.$; 102 $\left.23^{\prime} 47.5^{\prime \prime E}\right) 22$ Nov 2001 Pier poles. L. strigata. Site 9. Ban Salukpet, Ko Chang, Trat $\left(11^{\circ} 59^{\prime} 45.5^{\prime \prime} \mathrm{N} ; 102^{\circ} 22^{\prime} 32.5^{\prime \prime E}\right) 18-19$ Nov $2001 \mathrm{~A}$ few Avicennia marina $2-3 \mathrm{~m}$ high and house poles. $L$. pallescens, L. carinifera, L. strigata, L. articulata. Site 10. Laem Hin, Ban Prednai, Moeng, Trat $\left(12^{\circ} 9^{\prime} 48^{\prime \prime} \mathrm{N}\right.$; $102^{\circ} 34^{\prime} 36.3^{\prime \prime E)} 17$ Nov 2001 Rhizophora apiculata and Avicennia alba 5-7 m high and flat stones. $L$. carinifera, $L$. pallescens, $L$. melanostoma. Site 11. Ban Prednai mangrove, Moeng, Trat (127'38.9"N; 102 30'22.9"E) 7 Nov 2001 Sonneratia griffithii, Avicennia alba, A. marina, Rhizophora apiculata, R. mucronata, Ceriops tagal, Bruguiera cylindrica, and Xylocarpus granatum 5-10 m high. L. pallescens, $L$. carinifera, L. strigata, L. articulata, L. melanostoma. Site 12. Kung Kraben, Tamai, Chanthaburi (12 $33^{\prime} 54.1^{\prime \prime} N$; $\left.101^{\circ} 54^{\prime} 9 " \mathrm{E}\right) 15 \mathrm{Dec} 2002$ Plantation area, with plants $1.5-4$ $\mathrm{m}$ high, mostly $R$. apiculata, but also $R$. mucronata, Lumnitzera racemosa, Ceriops decandra, C. tagal, $A$. alba, $A$. marina and Sonneratia alba. L. pallescens, L. carinifera, $L$. strigata, L. articulata, L. melanostoma. Site 13. Tumbon Bankrum, Klaeng, Rayong (12³9'31.2"N; 101'39'52.3"E) 3 Dec 2001. Scattered $A$. alba, and some $R$. apiculata and $R$. mucronata and a small rock wall for protection from waves. $L$. pallescens, $L$. carinifera, $L$. strigata, $L$. articulata, $E$. trochoides. Site 14. Kord beach, Sattahip, Chonburi (12 $\left.41^{\prime} 45^{\prime \prime} \mathrm{N} ; 100^{\circ} 51^{\prime} 25.5^{\prime \prime} \mathrm{E}\right) .29$ Nov 2001 Scattered rocks. E. trochoides, E. vidua. Site 15. Krajong Bay, Ko Kram, Sattahip, Chonburi $\left(12^{\circ} 41^{\prime} 15.5^{\prime \prime N}\right.$; $\left.100^{\circ} 46^{\prime} 47.5^{\prime \prime} \mathrm{E}\right) 26$ Jan 2002 Rocky shore. E. feejeensis, E. trochoides, E. vidua, $P$. roepstorffiana. Site 16. Kam Bay, Ko Kram, Sattahip, Chonburi $\left(12^{\circ} 41^{\prime} 9.8^{\prime \prime} \mathrm{N}\right.$; $\left.100^{\circ} 47^{\prime} 38.5^{\prime \prime E}\right) 27$ January 2002 Scattered rocks. E. trochoides, E. vidua, $P$. roepstorffiana. Site 17. Ko Yor, Sattahip, Chonburi $\left(12^{\circ} 37^{\prime} 1.5^{\prime \prime N}\right.$; $100^{\circ} 53^{\prime} 7.5^{\prime \prime E) ~} 27$ Jul 2002 Scattered rocks. E. feejeensis, E. trochoides, E. vidua, $P$. roepstorffiana, $L$. strigata. Site 18 . Ko Larn, Pattaya, Chonburi (12054'58.2"N; 10046'19.4"E) 23 Feb 2002 Rocks. E. trochoides, E. vidua, P. roepstorffiana.

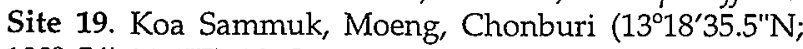
$\left.100^{\circ} 54^{\prime} 21.4^{\prime \prime E}\right) 30$ Oct 2002 Rocky shore. L. strigata, L. articulata, E. trochoides. Site 20. Bang Prong canal, Angsila,

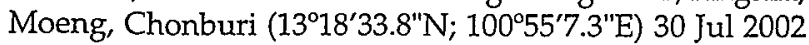
A. marina, S. griffithii and Sesuvium portulacastrum. $L$. pallescens, L. strigata, L. articulata, L. melanostoma, $L$. carinifera. Site 21. Samed, Moeng, Chonburi (13020'21.2"N; $\left.100^{\circ} 57^{\prime} 31.7^{\prime \prime} \mathrm{E}\right) 4$ Nov 2002 A. alba $4-7 \mathrm{~m}$ high. L. strigata, L. articulata, L. melanostoma. Site 22. Bangpu, Bangpu, Samut Prakarn (1330'39.7"N; $100^{\circ} 38^{\prime} 56.2^{\prime \prime E) ~ 21 J u l ~} 2002 A$. marina and $A$. alba 3-7 $\mathrm{m}$ high and rocks. L. strigata, L. articulata, L. melanostoma. Site 23. Had, Laemloung, T.Laempukbia, Banlaem, Phetchaburi $\left(13^{\circ} 2^{\prime} 13.4 " \mathrm{~N} ; 100^{\circ} 5^{\prime} 50.3^{\prime \prime} \mathrm{E}\right) 14 \mathrm{Dec} 2002$ R. apiculata, $R$. mucronata, and $A$. alba 7-10 $\mathrm{m}$ high. L. strigata, $L$. articulata, L. melanostoma, L. carinifera. Site 24. PTT mangrove, T. Paknampran, Pranburi, Prachuap Khiri Khan (12²3'17.5"N; 99059'2.3"E) 9 Dec 2002 A. marina, $R$. mucronata, and $R$. apiculata 3-4 $\mathrm{m}$ high. $L$. strigata, $L$. articulata, L. melanostoma, L. carinifera. Site 25 . E-led canal, Chumphon Islands Marine Park, Chumphon $\left(10^{\circ} 21^{\prime} 1.2^{\prime \prime N}\right.$; $\left.99^{\circ} 14^{\prime} 2.1^{\prime \prime E}\right) 24 \mathrm{Dec} 2001 R$. apiculata and $R$.. mucronata $15 \mathrm{~m}$ high, but some planted areas $1.5 \mathrm{~m}$ high. L. strigata, $L$. articulata, L. melanostoma, $L$. carinifera, $L$. pallescens. Site 26. Ban Cha-ngoe, Tumbon Takienthong, Kanjanadit, Surat Thani $\left(12^{\circ} 40^{\prime} 53.9^{\prime \prime N}\right.$; $\left.100^{\circ} 46^{\prime} 38.7^{\prime \prime} \mathrm{E}\right) 3$ Dec 2002. R. apiculata mixed with $A$. marina. $R$. mucronata and S. alba 5-15 m high. L. strigata, L. articulata, $L$. melanostoma. Site 27. Don Sak Ferry, Don Sak, Surat Thani $\left(9^{\circ} 19^{\prime} 55.7^{\prime \prime} \mathrm{N}\right.$; $\left.99^{\circ} 41^{\prime} 28.5^{\prime \prime} \mathrm{E}\right) 19$ Dec 2001 Rocks. $L$. strigata, L. articulata, E. trochoides. Site 28. Ban Taling ngam, Ko Samui, Surat Thani ( $9^{\circ} 42^{\prime} 47^{\prime \prime} N$; 99 $\left.58^{\prime} 33.7^{\prime \prime} E\right) 22$ Dec 2001 Granite rocks. L. strigata, L. articulata, E. trochoides. Site 29. Ko Kor Ma, Ko Pangun, Surat Thani (947'27"N; 99 58'52.8"E) 21 Dec 2001 Scattered rocks. $L$. strigata, L. articulata, E. trochoides, E. vidua. Site 30 Laem

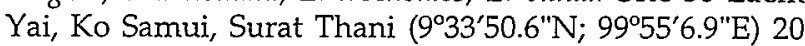
Dec 2001 Rocky shore. L. strigata, L. articulata, E. trochoides, E. vidua, E. feejeensis. Site 31. Hin Ta Hin Yai, Ko Samui Surat Thani 22 Dec 2001 ( $9^{\circ} 27^{\prime} 3.7^{\prime \prime N}$; $\left.100^{\circ} 2^{\prime} 37.5^{\prime \prime E}\right)$ Scattered granite rocks. L. strigata, $L$. articulata, E. trochoides. Site 32. Tumbon Pak Nakorn, Moeng, Nakhon Si Thammarat ( $\left.8^{\circ} 28^{\prime} 7.8^{\prime \prime} \mathrm{N} ; 100^{\circ} 3^{\prime} 52.9^{\prime \prime} \mathrm{E}\right)$ 28 Aug 2002 R. mucronata, $A$. alba and A. marina $2-4 \mathrm{~m}$ high. L. strigata, L. articulata, L. melanostoma, L. pallescens. Site 33 Pak Panung Bay, Pak Panung, Nakhon Si Thammarat $\left(8^{\circ} 23^{\prime} 40.7^{\prime \prime} \mathrm{N} ; 100^{\circ} 10^{\prime} 18.5^{\prime \prime} \mathrm{E}\right) 27$ Aug 2002. Mouth of Pak Panung canal. Mostly $R$. apiculata, and $R$. mucronata 5-15 m high. L. melanostoma. Site 34. Ban Laem. Tachi, Yaring, Pattani (6 $\left.6^{\circ} 5^{\prime} 40.8^{\prime \prime} \mathrm{N} ; 101^{\circ} 14^{\prime} 38.0^{\prime \prime} \mathrm{E}\right) 13$ Oct 2002 Rock seawall. L. strigata. Site 35. Ban Dee, Yaring, Pattani $\left(6^{\circ} 55^{\prime} 15.5^{\prime \prime} \mathrm{N}\right.$; $\left.101^{\circ} 19^{\prime} 35.5^{\prime \prime E}\right) 13$ Oct $2002 R$. mucronata $5 \mathrm{~m}$ high in Pattani Bay. L. pallescens. Site 36. Ban Da To, Yaring, Pattani (6 $54^{\prime} 18.4^{\prime \prime N}$; 10120'19.2"E) 13 Oct 2002 A. marina 4-5 m high, Pattani Bay. L. strigata, $L$. melanostoma, L. carinifera, L. intermedia. Site 37. KaeKae Beach,Tumbon Nambo, Panarei, Pattani (6 $6^{\circ} 0^{\prime} 16.3^{\prime \prime N}$; 101033'28.9"E) 4 Dec 2002 Scattered rocks. E. trochoides. Site 38. Naratat Beach, Moeng, Narathiwat (6 $26^{\prime} 32.5^{\prime \prime} \mathrm{N}$; $\left.101^{\circ} 49^{\prime} 18.6^{\prime \prime E}\right) 4$ Dec 2002 Small L. racemosa and Nypa fruticans. $L$. carinifera, $L$. pallescens. Site 39 . Ban Je Bilung, Je Bilung, Satun (638'21.2"N; 99 58'3.8'E) 5 Dec 2002. R. apiculata and R. mucronata 5-10 m. L. carinifera, Littoraria conica, $L$. bengalensis, $L$. melanostoma. Site 40 . Petra Is. Nat.Park, Tumbon Pakbara, Langu, Satun $\left(6^{\circ} 49^{\prime} 43^{\prime \prime}\right.$; $99^{\circ} 45^{\prime} 31.1^{\prime \prime E)} 5$ Dec 2002 Scattered A. marina 3-4 m high. L. strigata. Site 41 . Chaomai Beach, Kun Tung, Trang (7018'5.5"N; (99 24'19.1"E) 31 Aug 2002 A. alba, A. marina, and $S$. griffithii. L. pallescens, $L$. strigata, L. intermedia, $L$. bengalensis, L. scabra, E. trochoides. Site 42. Pak Meng Beach, Tumbon Ko Libong, Kun Tung, Trang (7²7'37.6"N; 99²0'23.6"E) 6 Dec 2002 A. marina 3-5m high. L. carinifera, L. bengalensis, L. strigata. Site 43 . Shell cemetery,Tumbon Saithai, Moeng, Krabi $\left(8^{\circ} 00^{\prime} 53.2^{\prime \prime N}\right.$; $\left.98^{\circ} 53^{\prime} 11.8^{\prime \prime E}\right) 6$ Dec 2002 Rocky shore and dead wood. $L$. 
strigata, E. trochoides. Site 44 . Ta la Beach, Tumbon Ban pa klok, Talang, Phuket ( $8^{\circ} 1^{\prime} 10.8^{\prime \prime N}$; 98²4'51.2"E) 7 Dec 2002 A. marina, R. mucronata, and S. griffithii 5-7 m high. $L$. pallescens, L. strigata, L. bengalensis. Site 45. Kalim Beach, Kratu, Phuket (7054'11"N; 98 $\left.17^{\prime} 53.6^{\prime \prime} E\right) 7 \mathrm{Dec} 2002$ Scattered rocks. L. undulata, E. trochoides, E. vidua, E. feejeensis. Site 46. Mai ngarm Bay, Ko North Surin, Phangnga (926'27.7"N; 97 $\left.52^{\prime} 48.5^{\prime \prime} \mathrm{E}\right) 20$ Apr 2002 Rocky shore with scattered $R$. apiculata and $R$. mucronata. $E$. trochoides, E. vidua, $P$. roepstorffiana, $L$. undulata, $L$. intermedia, L. scabra, L. pallescens. Site 47. Ko Jong,

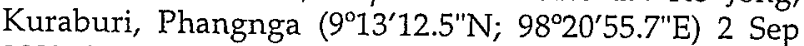
2002 A. marina, R. mucronata, and S. griffithii. L. scabra, $L$. strigata, $L$. bengalensis, $L$. pallescens, E. vidua, E. trochoides. Site 48. Ko Ra, Kuraburi, Phangnga (9 $15^{\prime} 21.5^{\prime \prime} N$; $98^{\circ} 22^{\prime} 30.5^{\prime \prime E)} 2$ Sep 2002 Rocky shore. E. trochoides, E. vidua, P. roepstorffiana, L. undulata, L. strigata. Site 49. Laem Mai Kaew, Ban Ta lei nok, Tumbon Naka, Suksumran sub-amphur, Ranong ( $9^{\circ} 27^{\prime} 58.5^{\prime \prime N}$; $\left.98^{\circ} 26^{\prime} 13.9^{\prime \prime E}\right) 3$ Sep 2002 Finlaysonia maritima, C. decandra and Aegialites rotundifolia. $L$. carinifera, $L$. melanostoma, $L$. bengalensis, L. conica, L. pallescens. Site 50. Klong Kone, Tumbon Klong Kone, Moeng, Samut Songkram

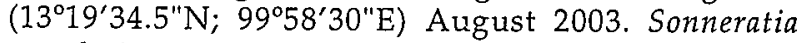
caseolaris, 5-10 $\mathrm{m}$ high. L. articulata, L. strigata, $L$. melanostoma. 


\section{Guide to Authors}

\section{Subject Matter:}

Reviews, observations and results of research into all branches of natural science and human studies will be considered for publication. However, emphasis is placed on studies pertaining to Western Australia. Longer papers will be considered for publication as a Supplement to the Records of the Western Australian Museum. Short communications should not normally exceed three typed pages and this category of paper is intended to accommodate observations, results or new records of significance, that otherwise might not get into the literature, or for which there is a particular urgency for publication. All material must be original and not have been published elsewhere.

\section{Presentation:}

Authors are advised to follow the layout and style in the most recent issue of the Records of the Western Australian Museum including headings, tables, illustrations and references.

The title should be concise, informative and contain key words necessary for retrieval by modern searching techniques. An abridged title (not exceeding 50 letter spaces) should be included for use as a running head.

An abstract must be given in full length papers but not short communications, summarizing the scope of the work and principal findings. It should normally not exceed $2 \%$ of the paper and should be suitable for reprinting in reference periodicals.

The International System of units should be used.

Numbers should be spelled out from one to nine in descriptive text; figures used for 10 or more. For associated groups, figures should be used consistently, e.g. 5 to 10 , not five to 10 .

Spelling should follow the Concise Oxford Dictionary.

Systematic papers must conform with the International Codes of Botanical and Zoological Nomenclature and, as far as possible, with their recommendations.

Synonymies should be given in the short form (taxon, author, date, page) and the full reference cited at the end of the paper. All citations, including those associated with scientific names, must be included in the references.

\section{Manuscripts:}

The original and two copies of manuscripts and figures should be submitted to the Editors, c/Publications Department, Western Australian Museum, Francis Street, Perth, Western Australia 6000. They must be in double-spaced typescript on A4 sheets. All margins should be at least $30 \mathrm{~mm}$ wide. Tables plus heading and legends to illustrations should be typed on separate pages. The desired position for insertion of tables and illustrations in the text should be indicated in pencil. Tables should be numbered consecutively, have headings which make them understandable without reference to the text, and be referred to in the text.

High quality illustrations are required to size $(16.8 \mathrm{~cm} \times 25.2 \mathrm{~cm})$ or no larger than $32 \mathrm{~cm} \times 40$ $\mathrm{cm}$ with sans serif lettering suitable for reduction to size. Photographs must be good quality black and white prints, not exceeding $16.8 \mathrm{~cm} \times 25.2 \mathrm{~cm}$. Scale must be indicated on illustrations. All maps, line drawings, photographs and graphs, should be numbered in sequence and referred to as Figure/s in the text and captions. Each must have a brief, fully explanatory caption. On acceptance a computer disk containing all corrections should be sent with amended manuscript. The disk should be marked with program (e.g. Word, WordPerfect, etc).

In papers dealing with historical subjects references may be cited as footnotes. In all other papers references must be cited in the text by author and date and all must be listed alphabetically at the end of the paper. The names of journals are to be given in full.

\section{Processing:}

Papers and short communications are reviewed by at least two referees and acceptance or rejection is then decided by the editors.

The senior author is sent one set of page proofs which must be returned promptly.

The senior author will receive fifty free offprints of the paper. Additional offprints can be ordered at page proof stage. 


\section{Records of the Western Australian Museum Volume 22 Part 32004}

\section{CONTENTS}

H. Smit

The water mite genus Koenikea Wolcott from Australia (Acari: Hydrachnidia: Unionicolidae)

\section{T. Karanovic}

The genus Metacyclops Kiefer in Australia (Crustacea: Copepoda: Cyclopoida), with description of two new species

\section{S. Martin, K.J. McNamara}

First record of a neolampadoid echinoid from the Paleogene of

Western Australia

N.R. Gunawardene, J.D. Majer

Ants of the southern Carnarvon Basin, Western Australia: An investigation into patterns of association

K. Sanpanich, F.E. Wells and Y. Chitramvong

Distribution of the family Littorinidae (Mollusca: Gastropoda) in Thailand 